\title{
Determination of 16 Elements in Tobacco by Neutron Activation Analysis*
}

\author{
by A. Wyttenbach, S. Bajo and A. Haekkinen \\ Institut Fédéral de Recherches en Matière de Réacteurs, Würenlingen, Switzerland
}

\section{INTRODUCTION}

Although there are several recent studies $(x-3)$ on trace elements in tobacco by neutron activation analysis, it is difficult for the reader not familiar with activation analysis to grasp what this technique can do in helping him to establish analytical data for tobacco products, how fast he can get the results and what precision he can expect. The present communication concentrates on these methodological questions and the findings are exclusively restricted to analytical implications. The pertinent data have been obtained from a great number of analyses of different raw tobaccos and are thought to be representative. Elements determined by instrumental neutron activation analysis are $\mathrm{Al}, \mathrm{Ca}, \mathrm{Mg}, \mathrm{Cl}$, $\mathrm{Mn}, \mathrm{K}, \mathrm{Na}$ and $\mathrm{Br}$, elements determined by neutron activation analysis with subsequent radiochemical separation $\mathrm{Hg}, \mathrm{Cu}, \mathrm{Mo}, \mathrm{Cd}, \mathrm{As}, \mathrm{Sb}, \mathrm{Zn}$ and $\mathrm{Co}$.

\section{GENERAL TECHNIQUES}

The following section does not contain information on the general principles of activation analysis, which are amply covered by many textbooks. It is restricted to points that are specifically related to the neutron activation analysis of raw tobacco.

\section{Sample Preparation}

The raw tobacco was dried for $80 \mathrm{~min}$ at $105^{\circ} \mathrm{C}$, which resulted in a weight loss of 10-15\%. It was then ground and kept in air-tight bottles.

\section{Sample Encapsulation}

$100 \mathrm{mg}$ of the sample are encapsuled in containers of especially pure polyethylene. If $\mathrm{Hg}$ is to be determined the sample has to be encapsuled in quartz vials, since it is well known that the use of polyethylene containers results in low $\mathrm{Hg}$ values $(4,5)$.

\section{Activation}

For irradiations up to zo minutes a pneumatic transfersystem with a time of transport of 6 seconds is used (6).

- Receired for publication: 7th October, 1975.
The irradiation position inside the reactor has a flux of $4^{\cdot} 10^{13} \mathrm{n} / \mathrm{cm}^{2} \mathrm{~s}$ and a flux gradient of less than $x \%$ over the volume of the transport container. It is thus possible to irradiate several samples and standards together under exactly the same conditions. Longer irradiations are made in a conventional irradiation position.

\section{Sample Dissolution}

For the determination of $\mathrm{Hg}, \mathrm{Cu}, \mathrm{Mo}, \mathrm{Cd}, \mathrm{As}, \mathrm{Sb}, \mathrm{Zn}$ and $\mathrm{Co}$ the sample has to be chemically processed, since the small activities resulting from these elements are completely masked by the much larger ${ }^{21} \mathrm{Na}$-activity. Dissolution is done as follows: The irradiated quartz vial is cooled in liquid nitrogen and broken; $100 \mu \mathrm{g}$ of each element are then added as carrier and the sample is gently heated with $10 \mathrm{ml}$ concentrated $\mathrm{HNO}_{3}$ and $5 \mathrm{ml} \mathrm{HClO}_{4}(60 \%)$ in a beaker. The resulting solution is transferred into a $700 \mathrm{ml}$ borosilicate glass volumetric flask fitted with an air condenser and heated on a hot plate (surface temperature: $250^{\circ} \mathrm{C}$ ) to white fumes, which takes about 2 hours. The resulting clear solution is brought to $100 \mathrm{ml}$ and $\left[\mathrm{H}^{+}\right]=0.1$ and is ready for extraction.

\section{Counting}

All samples are counted for their $\gamma$-activity, the following counters being used:

- a thin Si-detector for the fraction containing $\mathrm{Hg}$;

- a well-type Ge(Li)-detector for all other chemically processed samples;

- a flat $40 \mathrm{~cm}^{3} \mathrm{Ge}(\mathrm{Li})$-detector for all unprocessed samples, which are counted together with their polyethylene containers.

\section{Evaluation of Data}

The registered $\gamma$-spectra are stored on magnetic tape and processed off-line by computer. If a suitable standard has been irradiated and counted together with the samples, the computer is programmed $(7)$ to list the concentrations of all interesting elements in the samples together with their statistical errors. 


\section{DETERMINATION OF THE INDIVIDUAL ELEMENTS}

$\mathrm{Al}, \mathrm{Ca}, \mathrm{Mg}, \mathrm{Cl}$

The samples are irradiated for $1 \mathrm{~min}$ and measured without any further treatment for $100 \mathrm{~s}$ after a waiting time of 1.5 to $10 \mathrm{~min}$. The $\gamma$-spectra are checked for the following activities (the half-life and the energy of the evaluated $\gamma$-lines are given in brackets):

${ }^{28} \mathrm{Al}(2.25 \mathrm{~min}, 1779 \mathrm{keV}),{ }^{49} \mathrm{Ca}(8.7 \mathrm{~min}, 3084 \mathrm{keV})$, ${ }^{27} \mathrm{Mg}(9.5 \mathrm{~min}, 1014 \mathrm{keV}),{ }^{88} \mathrm{Cl}(37 \mathrm{~min}, 1642 \mathrm{keV}$, $2167 \mathrm{keV})$.

$\mathrm{Mn}, \mathrm{K}, \mathrm{Na}, \mathrm{Br}$

The same samples as used above are irradiated a second time (for $4 \mathrm{~min}$ ) and measured without any further treatment for $5 \mathrm{~min}$ after a waiting time of 20 hours. The following activities are evaluated:

${ }^{50} \mathrm{Mn}$ (2.58 h, $\left.847 \mathrm{keV}\right)$, ${ }^{42} \mathrm{~K}$ (12.4 h, $\left.1525 \mathrm{keV}\right)$, ${ }^{24} \mathrm{Na}(15.0 \mathrm{~h}, 1369 \mathrm{keV}),{ }^{62} \mathrm{Br}(35.3 \mathrm{~h}, 776 \mathrm{keV})$.

\section{$\mathrm{Hg}, \mathrm{Cu}, \mathrm{Mo}, \mathrm{Cd}, \mathrm{As}, \mathrm{Sb}, \mathrm{Zn}, \mathrm{Co}$}

The samples are irradiated to a neutron dose of 2. $10^{17} \mathrm{n} / \mathrm{cm}^{2}$ and dissolved as described above after a waiting time of 36 hours. Individual elements or groups of elements are then isolated by the method of subsequent extractions with different metal-dithiocarbamates into $\mathrm{CHCl}_{3}$ (8); the following fractions are extracted:

by $\mathrm{NiDDC}_{2}^{*}$

by $\mathrm{BiDDC}_{3}$ : ${ }^{197} \mathrm{Hg}(64 \mathrm{~h}, 77 \mathrm{keV})$,

by $\mathrm{ZnDDC}_{2}$ (I) before reduc- $\quad{ }^{99} \mathrm{Mo}(66 \mathrm{~h}, 14 \mathrm{IkeV})$, tion of the aqueous phase $\quad{ }^{115} \mathrm{Cd}(53.4 \mathrm{~h}, 336 \mathrm{keV})$,

by $\mathrm{ZnDDC}_{2}$ (II) after reduc- ${ }^{76} \mathrm{As}(26.4 \mathrm{~h}, 560 \mathrm{keV})$, tion of the aqueous phase : ${ }^{122} \mathrm{Sb}(2.7 \mathrm{~d}, 564 \mathrm{keV})$,

by HDDC after bringing the ${ }^{69 m} \mathrm{Zn}_{\mathrm{n}}(13.9 \mathrm{~h}, 439 \mathrm{keV})$, aqueous phase to $\mathrm{pH}_{5} \quad{ }^{60} \mathrm{Co}(5.3 \mathrm{y}, 1173 \mathrm{keV}$, $1332 \mathrm{keV})$.

The organic extracts are evaporated to $3 \mathrm{ml}$ and counted immediately after extraction except for the fraction $\mathrm{ZnDDC}_{2}$ (I) which is delayed for 24 hours in order to leave sufficient time for the establishment of the ${ }^{99} \mathrm{Mo} /$ ${ }^{90 \mathrm{~m}} \mathrm{Tc}$ and the ${ }^{115} \mathrm{Cd} / 115 \mathrm{~m}$ In equilibria. Counting times range from $5 \mathrm{~min}\left(\mathrm{BiDDC}_{3}\right)$ to several hours $\left(\mathrm{NiDDC}_{2}\right.$, HDDC).

\section{RESULTS AND DISCUSSION}

It is well known that the dissolution step is critical when either $\mathrm{Hg}$ (9) or As (10) is to be determined in an organic sample. Incomplete destruction of the organic material will lead to incomplete recovery of As,

- DDC: diethyldithiocarbamate anion.
Table 1. Summary of analytical results.

\begin{tabular}{|c|c|c|c|c|c|c|c|}
\hline $\begin{array}{c}\text { El- } \\
\text { ement }\end{array}$ & \multicolumn{3}{|c|}{$\begin{array}{l}\text { Range found in } \\
20 \text { different } \\
\text { raw tobaccos }\end{array}$} & \multirow{3}{*}{$\begin{array}{l}\text { ppm } \\
\% \%\end{array}$} & \multirow{2}{*}{$\begin{array}{c}\begin{array}{c}\text { Coeffi- } \\
\text { clent of } \\
\text { variation }\end{array} \\
3 \%\end{array}$} & \multirow{2}{*}{\begin{tabular}{|c}
$\begin{array}{c}\text { Number } \\
\text { of rep- } \\
\text { licates }\end{array}$ \\
20
\end{tabular}} & \multirow{2}{*}{$\begin{array}{l}\text { Capac- } \\
\text { Ity/ } \\
\text { day }\end{array}$} \\
\hline Al & 200 & - & 2300 & & & & \\
\hline $\mathrm{Ca}$ & 1.5 & - & 4.0 & & $4 \%$ & 20 & \\
\hline $\mathrm{Mg}$ & 3800 & - & 6600 & ppm & $7 \%$ & 20 & 30 \\
\hline $\mathrm{Cl}$ & 3600 & - & 16400 & ppm & $3 \%$ & 20 & \\
\hline$M n$ & 40 & - & 790 & ppm & $3 \%$ & 11 & \\
\hline$K$ & 1.7 & - & 6.2 & $\%$ & $2 \%$ & 11 & \\
\hline $\mathrm{Na}$ & 150 & - & 900 & ppm & $4 \%$ & 11 & 40 \\
\hline $\mathrm{Br}$ & 50 & - & 330 & ppm & $3 \%$ & 11 & \\
\hline $\mathrm{Hg}$ & 0.01 & $5-$ & 0.060 & ppm & $5 \%$ & 3 & \\
\hline $\mathrm{Cu}$ & 8 & - & 23 & ppm & $3 \%$ & 5 & \\
\hline Mo & 0.4 & - & 1.8 & ppm & $2 \%$ & 4 & \\
\hline Cd & 1.1 & - & 2.0 & ppm & $3 \%$ & 4 & 5 \\
\hline As & 0.26 & - & 0.66 & ppm & $4 \%$ & 4 & \\
\hline Sb & 0.05 & - & 0.33 & ppm & $10 \%$ & 4 & \\
\hline $\mathrm{Zn}$ & 30 & - & 79 & ppm & $3 \%$ & 4 & \\
\hline Co & & & $\sim 0.3$ & ppm & $4 \%$ & 4 & \\
\hline
\end{tabular}

and too high a temperature will cause losses of $\mathrm{Hg}$ and As by distillation. The adopted procedure was checked by spiking inactive tobacco samples with ${ }^{76} \mathrm{As}$ and ${ }^{20}{ }^{2} \mathrm{Hg}$ as radioactive tracers; losses through the whole dissolution and extraction steps were found to be less than $1 \%$ for As ( 3 samples) and less than $3 \%$ for $\mathrm{Hg}$ (6 samples). It is thus concluded that the dissolution procedure works satisfactorily.

A summary of the analytical results is given in Table 1. The range given covers the smallest and largest values found for every element in the analyses of 20 raw tobaccos of different origin. The sensitivity of the determinations was found adequate in the whole range of values encountered in this work. The coefficient of variation* was established by measuring $n$ replicates of one typical sample. Typically, the coefficient of variation is $4 \%$, which is the combined effect of sample inhomogeneity, weighing error, neutron flux gradient, timing errors and errors due to the statistical nature of radioactive decay. $\mathrm{Mg}$ and $\mathrm{Sb}$ show larger coefficients of variation; while the reason for $\mathrm{Sb}$ is not known, in the case of $\mathrm{Mg}$ it is due to the very small ${ }^{27} \mathrm{Mg}$ activity compared to the activity of the whole sample.

The capacity is given as the number of samples that one person can handle in a working day; it is seen that while the capacity is quite high for elements that can be determined by purely instrumental analysis, the necessity for dissolution and chemical separations in the other determinations results in a drastic diminution of the capacity.

The time necessary to produce analytical results is short

1 The coefficient of variation is the relative standard deviation of one single measurement and defined by

$$
100 \%\left[\sum_{1}^{n}\left(x_{i}-\bar{x}\right)^{2} / n-1\right]^{1 / 2} / \bar{x},
$$

where $\bar{x}$ is the mean, $x$ the measured values and $n$ the number of samples. 
if only the handling and cooling times are considered: approximately $\mathrm{I}$ day for $\mathrm{Al}, \mathrm{Ca}, \mathrm{Mg}, \mathrm{Cl}$ and $\mathrm{Mn}, 2$ days for $\mathrm{Na}, \mathrm{K}$ and $\mathrm{Br}$, and 4 days for the remaining elements. However, the availability of the necessary irradiation, counting and computing facilities can introduce a longer turn-round time.

Finally, a word should be said about the possibilities of determining further elements. Pushing dhemical separation further than was done in this work would allow more elements to be determined. To give just one example, adding an extraction step with HDEHP will allow the determination of Sc, La and some of the rare earths; this could be done without significantly increasing the turn-round time and presumably with the same precision. It is also possible to work without chemical separations $(2,3)$, but in this case a cooling time of one to two months has to be adhered to. This of course increases the turn-round time very much, while restricting the elements that can be determined to those elements giving rise to long-life activities; moreover the precision attained seems to be in many cases considerably less than $10 \%$.

\section{SUMMARY}

The determination of 16 elements in raw tobacco by neutron activation analysis is discussed. The 8 elements $\mathrm{Al}, \mathrm{Ca}, \mathrm{Mg}, \mathrm{Cl}, \mathrm{Mn}, \mathrm{K}, \mathrm{Na}$ and $\mathrm{Br}$ can be determined by purely instrumental means; this leads to a high sample capacity per working day and to a fast availability of analytical results. Contrary to this, the determination of the heavy metals $\mathrm{Hg}, \mathrm{Cu}, \mathrm{Mo}, \mathrm{Cd}, \mathrm{Zn}$, $\mathrm{Co}, \mathrm{As}$ and $\mathrm{Sb}$ has to be preceded by chemical separation which is accomplished by extractions with different metal-diethyldithiocarbamates as reagents. The variation coefficient is typically $\pm 4 \%$. The lowest and highest values of the concentrations which were found in the analysis of 20 different raw tobaccos are given.

\section{ZUSAMMENFASSUNG}

Es wird der Einsatz der Neutronenaktivierungsanalyse zur quantitativen Bestimmung von 16 Elementen in Rohtabakproben diskutiert. 8 Elemente, nämlich $\mathrm{Al}, \mathrm{Ca}$, $\mathrm{Mg}, \mathrm{Cl}, \mathrm{Mn}, \mathrm{K}, \mathrm{Na}$ und $\mathrm{Br}$ lassen sich rein instrumentell erfassen, was einen großen Probedurchsatz pro Arbeitstag und ein rasches Ermitteln der Analysendaten erlaubt. Demgegenüber müssen die Schwermetalle $\mathrm{Hg}, \mathrm{Cu}, \mathrm{Mo}$,
$\mathrm{Cd}, \mathrm{Zn}, \mathrm{Co}, \mathrm{As}$ und $\mathrm{Sb}$ nach einer chemischen Abtrennung mit verschiedenen Metalldiäthyldithiocarbamaten als Reagenzien bestimmt werden. Der Variationskoeffizient der Bestimmungen beträgt typisch $\pm 4 \%$. Die minimalen und maximalen Gehalte, die bei der Untersuchung von 20 verschiedenen Rohtabaken gefunden wurden, werden zusammengestellt.

\section{RESUME}

On décrit une méthode permettant le dosage de 16 éléments dans le tabac brut par activation par les neutrons. Les éléments $\mathrm{Al}, \mathrm{Ca}, \mathrm{Mg}, \mathrm{Cl}, \mathrm{Mn}, \mathrm{K}, \mathrm{Na}$ et $\mathrm{Br}$ peuvent être dosés d'une façon purement instrumentale, ce qui permet l'obtention rapide des résultats et la possibilité d'analyser de nombreux échantillons dans un temps très court. Par contre, le dosage de $\mathrm{Hg}, \mathrm{Cu}, \mathrm{Mo}$, $\mathrm{Cd}, \mathrm{Zn}, \mathrm{Co}$ et As exige des séparations himiques après l'irradiation, ce qui est fait en utilisant différents diéthyldithiocarbamates de métal comme extractants sélectifs. Le coefficient de variation typique monte à $4 \%$. On donne les seuils supérieurs et inférieurs des concentrations trouvées dans l'analyse de 20 différentes sortes de tabac brut.

\section{REFERENCES}

1. Maruyama, Y., K. Komiya, and T. Manri: Radioisotopes 19 (1970) 250.

2. Nadkarni, R. A., and W. D. Ehmann: Radiochem. Radioanal. Letters 4 (1970) 325.

3. Abedinzadeh, Z., and B. Parsa: J. Radioanal. Chem. 14 (1973) 139.

4. Bate, L. C.: Radiochem. Radioanal. Letters 6 (1971) 139.

5. Larson, J. O., and E. V. Tandeski: Anal. Chem. 47 (1975) 1159.

6. Wyttenbach, A.: Helv. Chim. Acta 52 (1969) 2458.

7. Schubiger, P. A., S. Chakraborty, A. Wyttenbad, and W. Blaser: J. Radioanal. Chem. 25 (1975) 141.

8. Wyttenbach, A., and S. Bajo: Anal. Chem. 47 (1975) $\times 813$.

9. Feldman, C.: Anal. Chem. 46 (1974) 1606.

10. Griffin, H. R., M. B. Hocking, D. G. Lowery: Anal. Chem. 47 (1975) 22.9.

The authors' address:

Institut Fédéral de Recherches en Matière de Réacteurs, CH-5303 Würenlingen, Suisse. 